\title{
Lexico-Grammatical Features of Nigerian English
}

\author{
Ajewole-Orimogunje Christiana-Oluremi \\ Department of General Studies, The Federal Polytechnic, Ede, Osun State, Nigeria
}

Tel: 234-803-506-3745_E-mail: remaje2005@yahoo.com

\begin{abstract}
Received: January 18, 2013 Accepted: February 23, 2013 Published: February 24, 2013
doi:10.5296/ijele.v1i1.3316 URL: http://dx.doi.org/10.5296/ijele.v1i1.3316
\end{abstract}

\begin{abstract}
English is a second language which serves a number of purposes in Nigeria and certain socio-cultural variables influence its use in the Nigerian context. There is rapid expansion in the vocabulary used by Nigerians to translate their thought into language. This has brought about different coinages to suit the situation and context of usage. The English language lacks the ability to perfectly capture all aspects of Nigerian culture, hence it is frequently augmented by fresh coinages and importations derived from Nigerian English lexis as different from native speakers' lexis. There is the introduction of culture-specific vocabulary items into the English language by Nigerian speakers of the language. This has led to creativity which manifests in coinages to reflect the Nigerian experience. Examples of Nigerian English are drawn and examined in this paper to reveal the influx of new words into the English language as occasioned by lexical derivations and innovations in the Nigerian usage of the language.
\end{abstract}

Keywords: Nigerian English, Second language, Lexis, Culture, Language teaching 


\section{Introduction}

The political phenomenon called Nigeria came into existence in 1914 as a result of the amalgamation of the Southern and Northern protectorates of the British territory around the River Niger area (Babajide 2001:1). The language situation in Nigeria today is very complex. As stated by Oyeleye 1994:98), it has been referred to as multilingual, but in purely pragmatic terms the norm has always been bilingual. He notes further that this is justified in the sense that in any practical situation requiring language interaction, there are two choices open to us: one of the local indigenous languages and English. The local languages are used in informal and non-official situations while English is reserved for formal situations. As rightly observed by Taiwo (2007:232), the increasing adoption of English as a second language has made a hybrid language to evolve in order to meet the cultural and communicative needs of the speakers. Nigeria has about 400 indigenous languages out of which three major ones - Yoruba, Hausa, and Igbo have attained national recognition. According to Babajide (ibid) the choice of these three languages was predicated on the fact that they are far more developed in linguistics and literature than the rest and they are more widely used in the country than the others.

Different scholars like Bamgbose (1992, 1995), Banjo (1995), Jowitt (1991), Adejare (1995) have established the inevitability of English in a second language situation and have dealt with variety differentiation and the pragmatic use of English in Nigeria. Bamgbose (1995:9-11) observes that the present form and status of English in Nigeria are as a result of the contact between English and Nigerian languages in the sociocultural and political situations. He identifies five dimensions of the influence of English in the Nigerian environment - educational, political, cultural, sociolinguistic and linguistic. The educational dimension concerns the language policy which entrenches English as the language of education; the political dimension concerns the emergence of an English-speaking elite and the role played by the language in the fight for independence as well as in the evolution of the various constitutions under which the country has hitherto been governed. The cultural dimension concerns the introduction of new concepts and values, as well as modes of interaction, as reflected in both Nigerian English and Nigerian languages. The sociolinguistic dimension concerns the mode of acquisition and use of English, and the emergence of bilingual elite speaking English and one or more Nigerian languages, while the linguistic dimension concerns the way English has permeated the vocabulary of Nigerian language and the sound system.

\section{Roles of English language in Nigeria.}

According to Babajide (2001:4-5) English is used in Nigeria in most situations: home, office, market etc and for all communication interaction: formal, informal, cordial, casual etc. He states further:

Given the many important roles that English language performs, it becomes expedient for any Nigerian that wants to be relevant to his social, economic, and political environment to learn and acquire some appreciable knowledge of English. This explains why both the literate and non-literate have a great 
respect for anyone who has an admirable proficiency in English. In fact, educated Nigerians who are deficient in their mastery of English, and some of the uneducated lot make frantic efforts through private tuition to learn it (2001:4).

Jowitt (1995:53) submits that it is likely that English will also remain an official language in Nigeria for a long time to come and it will probably continue to have much the same functions as at present. Alo (2004:78) highlights a variety of important functions of the English language in Nigeria:

a. Official language

b. The lingua franca among educated Nigerians

c. The medium of instruction in secondary and tertiary institution, including the last three years of primary education

d. A school subject

e. The principal language of wider communication, business, commerce, industry, public administration

f. The language of science and technology

g. An instrument of national, state and local politics

h. A medium of creative expression.

It is important to note that English also serves the purpose of uniting the various ethnic groups in Nigeria. On the importance of English as a language that unifies the different ethnic groups in Nigeria, Afolayan as cited by Jowitt (1991:23) posits:

It is unrealistic for anybody in Nigeria today to think that national unity can be forged in the country without recourse to the utilisation of the English language;... It has been the language of the creation of the political entity itself, and also the language of its political-economic unification and administration.... Furthermore, the fact that it is now functioning as the language of Nigerian nationalism cannot be denied.

Thus, English is the principal lingua franca of educated Nigerians, the principal medium of instruction in schools, the principal language of wider communication, and the principal medium of literary expression.

\section{The Place of English in the Nigerian Educational System}

As noted by Anwaruddin (2012), individuals learn a second language for a number of purposes - education, survival, professional development or personal enjoyment. In the area of education, language is an indispensable tool for the dissemination of knowledge not only to school pupils and students but also to the masses who have had the opportunity to go through the formal school system (Adeyanju 2004:67). According to The National Policy on 
Education (2004:11), English shall be the medium of instruction from the fourth year in Nigerian primary schools. Akindele and Adegbite (2005:118) remark that it is inevitable that for a long time to come, English will indisputably be the medium of instruction for higher education in Nigeria. They observe further that the language has no rival among the indigenous languages which are still far from being able to accommodate the expression of modern scientific and technological concepts. Ogunsiji (2001:158) however notes the negative effects of the roles of English language in Nigeria on the field of education. He argues that at the senior secondary level, a failure in English language almost amounts to academic failure as no candidate can gain admission to any tertiary institution in Nigeria without a credit pass at the school certificate level. Thus, according to him, some potential geniuses have been reduced to dropouts because of their inability to secure pass grades in the language. Odebunmi (2006:109) comments that the formality of the English spoken in Nigeria has been traced to the formal way in which English is taught in Nigerian schools. This, according to him has produced over the years lexical strait jacketed students who could not differentiate the formal from the informal variety of English. He states further that the general speakers of English in Nigeria, especially the elites go for the bookish variety of English because "such a use of the language is associated with knowledgeability and learnedness by Nigerians".

As observed by Jowitt (1991:54), the learning of English in Nigeria begins with the learning of simple greetings and the simplest grammatical structures by the primary school child. He states further:

\section{Formal learning continues through primary and secondary school up to GCE ' $O$ ' level and is continued and supposedly reinforced by 'Use of English' courses in higher institutions. It is certainly reinforced and powerfully, by informal learning outside the classroom, and this is of various kinds. Probably the most important is listening to other Nigerians who have achieved greater proficiency, and talking to other Nigerians who may be more or less confident.}

The learning of other subjects in the curriculum is reinforced by English as it serves as the medium for teaching other subjects apart from subjects like Yoruba, Hausa and Igbo which are taught by using the local languages as the medium of instruction.

\section{Nigerian English}

Nigerian English emerged as a result of the contact between native speakers and users of the English language in Nigeria. English is a second language which is learned and used with the various indigenous languages in Nigeria. Jowitt (1991: ix) notes that English is an everyday means of communication for large numbers of Nigerians of differing degrees of education. According to him, Nigerian English is something real and identifiable. This is corroborated by Osunbade as cited by Bemigho and Olateju (2006:150) who assert that "Nigerian English is therefore that variety of English that has developed in the Nigerian non-native English situation and it has distinguishing features manifested at the phonological, lexico-semantic, grammatical and discourse levels". 
Bemigho and Olateju (ibid) observe further that the English language emerged by the process of the acculturation of British English to the Nigerian socio-cultural environment after having been introduced by the British people, and as a result of the acculturation, the English language draws from the socio-cultural norms of Nigerians and is used to encode the experiences of the Nigerian people. As observed by Odebunmi (2006:107), the socio-cultural differences that exist between the English people and Nigerians allow new lexical items to develop. He states further that before the introduction of the English language in Nigeria, the indigenous languages were employed to express thoughts, customs, experiences, and the people's way of life and when English has now got a place in inter and intra-ethnic communication, new lexical items are bound to evolve. Ogunsiji (2007:7) observes that when a Nigerian speaks English, no matter his level of education, native speakers of English have no difficulty of identifying the speaker as a Nigerian because of the reflection of some structural characteristics of Nigerian languages.

Commenting on the characteristics of standard Nigerian English and the way it has been nativized, Bamgbose (1995:20-21) posits:

\begin{abstract}
Such nativization consists of three aspects: linguistic, pragmatic and creative....it is the aspect of linguistic nativization of Nigerian language vowels and consonants for English ones and replacement of stress by tone, pluralisation of some non-count nouns, introduction of culture-specific vocabulary items, back formation, semantic shift, different verb-preposition combinations and some Nigerian L1-induced syntactic structures.
\end{abstract}

In his views, Jowitt (1991:ix-x) affirms that 'Nigerianism' should not invariably be seen as evidence of the imperfect learning of English, but deserved to be considered as possible signs of acculturation, and of the creative capacity that we normally associate with mother tongue learning and use. According to him, we might regard Nigerian English as English that has England as its first mother and Nigeria as its second, and has defiled nature by undergoing a gynaecological re-processing, adding that there is no law of nature or man stipulating that a language must be considered the exclusive 'possession' of the people who were its first 'owner'.

\title{
4.1 Features of Nigerian English
}

Nigerian English is the variety of English that is broadly spoken and written by Nigeria's literary, intellectual, political and media elite across the regional and ethnic spectra of Nigeria (Kperogi 2007). The rapid expansion in the vocabulary used by Nigerians to translate their thought into language has brought about different coinages and expressions to suit the situation and context of usage. The inability of the English language to perfectly capture aspects of Nigerian culture has led to importation derived from Nigerian English lexis and culture-specific vocabulary items and creativity to reflect the Nigerian experience. Raji-Oyelade (2012) observes that Nigerians revel in the re-production of new vocabularies and artificial intelligence which determine how they write, socialize, the way they teach, read, and how they recreate. 
As expressed by Ogunsiji (2001:157), new words and expression are coined daily to express the Nigeria linguo-cultural realities. Alo (2006:26) also states that coinages are newly coined words and expression in English resulting from the prevailing socio-linguistic factors in Nigeria. Hence, according to Ogunsiji (ibid), we have expressions such as June 12 (the date of the annulled 1993 presidential election), 'step aside' (an expression used by General Ibrahim Babangida to describe his style of quitting office), 'four-one-nine' (high class fraud) 'operation sweep', 'operation wedge', 'presidential strike force' (security outfits) etc. As noted by Jowitt (1991), a very large number of words belong to the registers of food, dress, transport, religion and traditional customs. The following are some examples:

1. Akara (Yoruba) - fried cakes made of been flour

2. Buka (Hausa) - a cheap eating place

3. Ogbono (Igbo) - name of a soup

4. Agbada (Yoruba) - a large gown worn by men

5. Danshiki (Hausa) - gown with wide armpits worn by men.

Alo (2004:73) examines the interplay of language variations and context to explain the differences in usage and meaning of words. He used the word 'head' meaning 'ori' in Yoruba language to show the connotations of the word and its variation in different situations in the Yoruba context with the following examples:

i. His head is not correct.

ii. By my head, I beg you.

He explains that an interpretation of these expressions in Nigerian English would require some cultural knowledge of the Yoruba about their notion of human destiny, social behaviour, success etc. Hence, differences in the word 'head' in English and 'ori' in Yoruba can easily be observed and these relate to differences in socio-cultural contexts of the Nigerian (Yoruba) and British environments. The point being made is that, the same word may acquire different denotations and connotations and may acquire different meanings for different language users. Akindele and Adegbite (2005:5) note that language is connected to culture in three major ways. First, it is an aspect of culture, second, language is an instrument of thought which helps to concretize thought and also to explore, discover, extend and record the experiences in a culture, and third, it expresses culture.

There are a large number of lexical items and expressions which have undergone semantic change in Nigerian usage compared to British Standard English. Some examples are highlighted below.

- Academician - used to refer to an academic person instead of academic.

- Answer (e.g. He answers Tope) instead of 'His name is Tope'

- Burn to ashes - meaning completely burn (e.g. The man was burnt to ashes). 
- Bush meat - used to refer to the meat of wild animals killed by hunters (The British equivalent is 'game').

- Colonial masters - used to refer to the British in their role of exercising political control in Nigeria before independence.

- Correct (e.g. your head is not correct). A way of describing someone as a fool.

- $\quad$ Light - meaning electricity (e.g. There is no light).

- Long leg - personal connection with an influential person to obtain favour.

- Meet me well - a polite greeting inviting a visitor who arrives at one's house when one is eating to come and share the meal.

- Next tomorrow - meaning 'the day after tomorrow'

- Now now - meaning 'now' (e.g. I want to see you now now).

- Quick quick - meaning ‘quickly’ (e.g. come quick quick).

- One one naira - meaning one naira each.

Bamgbose as cited by Banjo (1995:228) draws attention to such locutions as 'sorry' and 'well done' which are often used as greetings in Nigerian English. The former as an expression of sympathy (e.g. to a person who sneezes) and the latter as a greeting to somebody at work. Also the expression 'thanks for yesterday' is used to show gratitude to somebody for favour done the previous day. We also have the use of 'not on seat' (e.g. Mr John is on seat) when Mr John is not on hand when required and 'I am coming' instead of 'I will be back'.

At the level of lexico-semantics, the influence of culture manifests in Nigerian English such that meaning of some words have been broadened. Kinship terms like father, mother, brother, sister, aunt have assumed different meanings. For example words like sister, brother, aunt are used as terms of respect for older people; they are used to replace kinship relationship such as cousin, nephew, niece etc. 'Father' and 'mother can be used for any elderly person who may not necessary be one's biological parents. Akindele and Adegbite (2005:5) explain the influence of social structure on syntactic structure with the following examples:

i. Yoruba: Ebi n pa mi (Hunger is killing me).

ii. Igbo: Aguru na agu m (hunger is beating me).

iii. Hausa: Ina jin yunwa (I am feeling hunger).

iv. English: I am hungry.

They observed that while the phenomenon controls the speakers in (i) and (ii), the speaker controls the phenomenon in (iii) and (iv). They state further that while cold 'kills' or 'beats' Yoruba and Igbo persons, the Hausa and English persons 'feel' or 'catch' this.

Alo (2004:80) notes that variation in word usage and meaning can also be seen in the application of greeting terms like 'congratulate / congratulations' and felicitate / felicitation' 
to express a variety of social functions. According to him, the terms 'congratulate' (verb) and 'congratulations' (a plural noun) are used in English to express the feeling that one is happy that somebody has achieved something. In the Nigerian context such forms are not only used in this sense but may be used to express other socio-cultural functions such as a means of demonstrating closeness, solidarity, unity, good will and the absence of hostility. Thus, the terms can be used for social events like birthdays, honours and awards, house warming, national independence anniversary etc. Akindele and Adegbite (2005:40) observe that at the grammatical level the system of the mother tongue intrudes into that of the target language because the two are of different models, and grammatical interference will depend on the level of the bilingual involved. They explain that at the primary school level for example we can have an utterance such as 'My stomach is very sweet' (meaning 'I am very happy') and 'They are calling you' instead of 'He/She is calling you'. In the second example, we have the use of the honorific plural pronoun 'they', where 'they' refers to a single person. This shows further the influence of culture (Yoruba) on the use of 'they' to show respect to an elderly person.

In the area of phonology, we have the problem of interference of the mother tongue on the pronunciation of some English words by Nigerian speakers of English. This occurs because some sounds in English are not available in some of the Nigerian languages. Hence, some Yoruba speakers of English often substitute the sound /f/ for $/ \mathrm{v} /$ and $/ \mathrm{s} /$ for $/ \mathrm{z} /$ and thereby pronounce wrongly words like:

van /væn/ as /fæn/; zoo/zu:/ as /su:/ etc.

Also, the articulation of the English phonemes /p/ and /f/ presents problems to Hausa speakers of English. For example /f/ is substituted for $/ \mathrm{p} /$ in the word 'people' pronounced as /fi:ful/ instead of/pi:pul/.

The Nigerian media have also introduced certain words and expressions into Nigerian English. For example - 'national cake' which means material wealth expected to be shared by citizens of Nigeria, and 'bottom power' meaning a favour that a woman gets through the use of feminine charms to gain social advantage. Other examples of the use Nigerian English are found in the following:

- The student had a carry over in GNS 101. (The student failed GNS 101)

- He entered the motor going to Lagos. (boarded the vehicle)

- He dropped down at Lagos. (alighted)

- Off the light/on the light. (switch on/off the light)

- There is go slow. (traffic jam)

- I want to attend the congress meeting. (congress or meeting)

- The car is overspeeding. (speeding)

- She delivered a baby. (delivered of a baby) 
- Presently, I am a student. (at present)

- He was attacked by men of the underworld. (armed robbers/criminals)

- The man bought a Tokunbo car. (used car)

- John is a been to. (one who has travelled abroad, and returned)

- The old man has joined his ancestors. (died)

- Jane has put to bed. (given birth to a child)

- She has four issues. (children)

- Ade bagged a degree in Engineering. (earned/received)

Also, Nigerian English features expressions such as of recent (meaning recently), instalmentally (in instalments), cow meat (beef), goat meat (mutton), globe (bulb), house girl (house help), letter-headed paper (letterhead) etc. The examples are numerous and cannot be exhausted in this paper.

\section{Conclusion}

The fact remains that the various cultural and socio-linguistic thought of Nigerians cannot be adequately expressed in the standard form of the English language. Hence, the different lexical derivations, innovations and improvisation to suit the situation and context of usage of the language. Researchers are still inconclusive about the characterisation of Nigerian English, but it is obvious that there is Nigerian English with its own peculiarities which are conditioned by the Nigerian socio-cultural environment (Ogunsiji 2004:87). As noted by Kperogi (2007), Nigerian English is not bad or substandard English; it is a legitimate national variety that has evolved out of our experiences as a post-colonial, polyglot nation. It is clear that English has become an important language which cannot be easily discarded in Nigeria. It has become a Nigerian language which has provided another means for Nigerians to express their culture. Its use in the educational sector will remain as long as there is no alterative to replace it.

\section{Recommendations}

Given the numerous roles of English language in Nigeria, the language should be given priority in its teaching and learning. This will go a long way in enhancing its use in all areas especially in the education system. Good books and other learning materials in the subject should be made available by the government and the syllabus at all levels of the education system should be made functional such that learners will find the subject more interesting. Nigerian teachers of English language should strive to improve on their teaching skills by using methodologies that will enable the students to gain competence in the use of the English language. 


\section{Macrothink}

International Journal of English Language Education

ISSN 2325-0887

2013, Vol. 1, No. 1

\section{References}

Adejare, O. (1995). Communicative competence in English as a second language. In Bamgbose, A., Banjo, A., \& Thomas A. (Eds), New Englishes (pp. 153-177). Ibadan: Mosuro Publishers.

Adeyanju, D. (2004). Historicity and language function: a case of the English language in Nigeria. In Oyeleye, L. (Eds), Language and discourse in society (pp 62-70). Ibadan: Hope publication.

Akindele, F., \& Adegbite, W. (2005). The sociology and politics of English in Nigeria. Ile-ife: O.A.U. Press.

Alo, M. A. (2004). Context and language variation: The EL2 example. In Oyeleye, L. (Ed), Language and discourse in society (pp. 73-82). Ibadan: Hope publication.

Alo, M. A. (2006). Creativity and lexical/discourse innovations in Yoruba-English translation. Ibadan Journal of English studies, 3, 17-36.

Anwaruddin, S. M. (2012). Learner identity in second language education. The Southeast Asian Journal of English language studies, 18(2), 13-23.

Babajide, A. O. (2001). Language attitude patterns of Nigerians. In Igboanusi; H (Ed), Language attitude and language conflict in West Africa (pp. 1-13). Ibadan: Enicrownfit Publishers.

Bamgbose, A. (1995). English in the Nigerian environment. In Bamgbose, A., Banjo, A., \& Thomas, A. (Eds), New Englishes (pp. 9-26). Ibadan: Mosuro Publishers.

Bamgbose, A. (1992). Standard Nigerian English: Issues of identification. In Kachru, B (Ed), The other tongues across cultures. Urbara: University of Illinois press.

Banjo, A. (1995). On codifying Nigerian English: research so far. In Bamgbose, A., Banjo, A., \& Thomas A. (Eds), New Englishes (pp. 203-231). Ibadan: Mosuro Publishers.

Bemigbo, V. (Olateju, M. (2007). The lexico-semantic features of Nigerian English in 'Kegites' discourse: The O.A.U. example. In Olateju, M. Taiwo, R., \& Fakoya, A. (Eds), Towards the understanding of discourse strategies. (pp. 149-170). Ago - Iwoye: Olabisi Onabanjo University Press.

Federal Republic of Nigeria. (2004). National policy on education.

Jowitt, D. (1991). Nigerian English usage: An introduction. Ikeja: Longman Nigeria Plc.

Jowitt, D. (1995). Nigeria's national language question: choice and constraints. In Bamgbose, A., Banjo, A., \& Thomas, A. (Eds), New Englishes (pp. 34-56). Ibadan: Mosuro Publishers.

Kperogi, F. A. (2007). Divided by a common language: Comparing Nigerian, American and British English. Retrieved from http://www.farooqkperogi.com/2007/09/divided-by-common-language-comparing.html 


\section{Macrothink \\ International Journal of English Language Education \\ ISSN 2325-0887 2013, Vol. 1, No. 1}

Odebumi, A. (2006). Meaning in English: an introduction. Ogbomoso: Critical sphere.

Ogunsiji, A. (2001). Utilitarian dimension of language in Nigeria. In Igboanusi, H., (Ed), Language attitude and language conflict in West African (pp. 152-164). Ibadan: Enicrownfit Publishers.

Ogunsiji, Y. (2007). English in a bilingual/bicultural, multilingual/multicultural environment. In Adeyanju, D. (Ed), Sociolinguistics in the Nigerian context (pp. 1-14). Ile-Ife: Obafemi Awolowo University Press.

Oyeleye, L. (1994). Problem of variety differentiation in Nigerian English: A sociolinguistic study. In Asein, S. O., \& Adesanoye, F. A. (Eds), Language and polity (pp. 97-111). Ibadan: Sam Bookman Education and Communication Services.

Raji-Oyelade, A. (2012). The treasures and taints of literacies in the digital age. Conference paper delivered at Obafemi Awolowo University, Ile-Ife, Nigeria.

Taiwo, R. (2007). Computer - mediated communication: Implications for the teaching and learning of English in Nigeria. In Olateju, M., Taiwo, R., \& Fakoya A. (Eds), Towards the understanding of discourse strategies (pp. 231-247). Ago-Iwoye: Olabisi Onabanjo University Press.

\section{Copyright Disclaimer}

Copyright reserved by the author(s).

This article is an open-access article distributed under the terms and conditions of the Creative Commons Attribution license (http://creativecommons.org/licenses/by/3.0/). 